\title{
Vertical Alveolar Crest Bone Maintenance Around Implants in Two-Stage Surgery: An In Situ Study in Dogs
}

\author{
Mário Roberto LEONARDO ${ }^{1}$ \\ Alberto Tadeu Nascimento BORGES ${ }^{1}$ \\ Walter MARTINS-JÚNIOR ${ }^{2}$ \\ Alexandra Mussolino de QUEIROZ ${ }^{1}$ \\ Sada ASSED ${ }^{1}$ \\ ${ }^{1}$ Department of Pediatric Clinics, Preventive and Community Dentistry, \\ Dental School of Ribeirão Preto, University of São Paulo, Ribeirão Preto, SP, Brazil \\ ${ }_{2}^{2}$ Periodontics, Private Practice, Ribeirão Preto, SP, Brazil
}

\begin{abstract}
The aim of this study was to evaluate in situ changes in the alveolar crest bone height around immediate implant-supported crowns in comparison to tooth-supported crowns (control) with the cervical margins located at the bone crest level, without occlusal load. In Group I, after extraction of 12 mandibular premolars from 4 adult dogs, implants from Branemark System (MK III TiU RP $4.0 \mathrm{x}$ $11.5 \mathrm{~mm}$ ) were placed to retain complete acrylic crowns. In Group II, premolars were prepared to receive complete metal crowns. Sixteen weeks after placement of the crowns (38 weeks after tooth extraction), the height of the alveolar bone crest was measured with a digital caliper. Data were analyzed statistically by the Mann-Whitney test at 5\% significance level. The in situ analysis showed no statistically significant difference $(\mathrm{p}=0.880)$ between the implant-supported and the tooth-supported groups $(1.528 \pm$ $0.459 \mathrm{~mm}$ and $1.570 \pm 0.263 \mathrm{~mm}$, respectively). Based on the findings of the present study, it may be concluded that initial periimplant bone loss may result from the remodeling process necessary to establish the biological space, similar to which occurs with tooth-supported crowns.
\end{abstract}

Key Words: immediate implants, alveolar bone crest, bone resorption, in situ evaluation.

\section{INTRODUCTION}

Immediate dental implant placement is a recent procedure to oral rehabilitation that has shown advantages, such as a smaller number of surgical procedures, lower cost and reduction of the edentulism period, compared to conventional technique (1). In addition, immediate implants have a better patient acceptance $(2,3)$ for allowing a good preservation of both height and width of the alveolar bone crest (4), resulting in satisfactory esthetics and improved intermaxillary relationship $(2,5)$. Maintenance of the alveolar bone crest dimensions has been observed around implants placed immediately after tooth extraction (5) as well as new bone formation in areas with alveolar infrabony defects (6). Also, cervical bone loss ratio is reduced around immediate implants placed in maxillary and mandibular posterior regions compared to delayed implants, mainly in poor bone quality areas (4).

The level of bone crest surrounding the implant is of utmost significance to determine osseointegrated implant success (7), as preservation of marginal bone height is highly important for long-term dental implant survival (8). Anatomic factors, such as the quality and architecture of bone tissue, as well as implant features, e.g., length, surface area, coating, implant timing (4) and occlusal load (9), may influence alveolar bone crest resorption.

Longevity is the most common parameter to evaluate the success of dental implants, and the maintenance of cervical bone around the implant is the main factor to determine such a positive outcome (10).

Corrrespondence: Profa. Alexandra Mussolino de Queiroz, Departamento de Clinica Infantil, Odontologia Preventiva e Social, Faculdade de Odontologia de Ribeirão Preto, Universidade de São Paulo, Avenida do Café S/N, 14040-904 Ribeirão Preto, SP, Brasil. Tel: +55-163602-4116. Fax: +55-16-3633-0999. e-mail: amqueiroz@forp.usp.br 
Schwartz-Arad et al. (4) have pointed out that the success of dental implants should be evaluated based on both clinical and radiographic parameters, which could indicate peri-implant bone loss.

The influence of the peri-implant alveolar bone crest level on the presence or absence of papillae between implants and adjacent teeth has been demonstrated (11). In this way, prediction of the amount of alveolar bone crest loss is important for a good esthetic outcome after placement of implant-supported crowns and dentures (12). This study evaluated in situ changes in the alveolar crest bone height around immediate implant-supported crowns in comparison to toothsupported crowns (control) with the cervical margins located at the bone crest level, without occlusal load.

\section{MATERIAL AND METHODS}

\section{Animal Procedures}

All animal procedures were performed according to the protocol reviewed and approved by the Ethics in Animal Research Committee of the University of São Paulo in compliance with the applicable ethical guidelines and regulations of the International Guiding Principles for Biomedical Research Involving Animals. The study was design according to the ISO 7405-1997 standard: Biological evaluation of dental materials (13).

Four 2-year-old adult mongrel dogs weighing $15-20 \mathrm{~kg}$ were used and received a standard diet with water ad libitum. The animals were anesthetized with $1 \%$ sodium thiopental (Thiopentax; Cristália Produtos Químicos Farmacêuticos Ltda., São Paulo, Brazil; 15 $\mathrm{mg} / \mathrm{kg}$ body weight, i.v.) and preoperative periapical radiographs of the premolar region were taken in order to localize dental roots and nerve region. A total of 24 mandibular premolars were assigned to 2 groups: Group I was composed by 12 implant-supported crowns (after premolar extraction) and Group II was composed by 12 natural tooth-supported crowns. Figure 1 describes the clinical procedures and timelines of the study. Before the surgical/prosthetic procedures, antisepsis of the oral cavity was performed with $3 \%$ hydrogen peroxide and $0.12 \%$ chlorhexidine gluconate followed by rubber cup/ pumice prophylaxis using sterile instruments.

In Group I, 3 mandibular premolars were extracted from each dog according to the following protocol: the first dog had the 2 nd and 4 th premolars extracted from the right side and the 3rd premolar extracted from the left side; the second dog had the 2nd and 4th premolars extracted from the left side and the 3 rd premolar extracted from the right side; in the other animals, the sides were alternated in a randomized manner. After gingival flap elevation, the teeth was decoronated with a 29 mm carbide Zekrya bur (Dentsply/ Maillefer, Ballaigues, Switzerland) under sterile saline irrigation, followed by gentle luxation of the roots with a straight elevator and extraction with a \#151 forceps. For each dog, 3 titanium Branemark System TiUnite MK III implants ( 4.0 x $11.5 \mathrm{~mm}$; Branemark System; Nobel Biocare AB, Gothenburg, Sweden) were inserted in the alveolar wounds immediately after extraction within the same session, according to the Nobel Biocare protocol.

For preparation of the receptor areas, a spearshaped guide bur (Nobel Biocare AB) was used to mark the site of implant placement in the intraradicular septum of the extracted teeth followed by a helicoidal bur ( $2 \mathrm{~mm}$ in diameter; $13 \mathrm{~mm}$ long) (Nobel Biocare $\mathrm{AB}$ ). The parallelism of each perforation was evaluated with a positioning device and a pilot bur ( $3 \mathrm{~mm}$ in diameter; 13 $\mathrm{mm}$ long) was used to enlarge its diameter from 2 to 3 . When necessary, the coronal portion of the perforation was widened in order to ensure that the implant platform and the alveolar bone crest were in the same level. All surgical burs (Nobel Biocare $A B$ ) were used under continuous and abundant saline irrigation and all procedures were performed at 2,000-3,000 rpm with an electronic torque controller (Torque Controller; Nobel Biocare AB, Gothenburg, Sweden). After preparation of the screw threads at $15-20 \mathrm{rpm}$, the implants were inserted and the cover screws were placed. A relaxing incision was made to allow the reposition of the flap over the implants and sutured with 4.0 silk sutures (Ethicon; Johnson and Johnson, São José dos Campos, SP, Brazil) and control periapical radiographs were taken.

After the surgical procedures, the animals were given a penicillin-based antibiotic $(600,000 \mathrm{IU})$, an antitoxic immunostimulant (Mercepton; Bravet, Rio de Janeiro, RJ, Brazil) and an analgesic (Tramadol chlorhydrate; Anangor; Laboratórios Biosintética Ltda., São Paulo, SP, Brazil) at a dose of $3 \mathrm{mg} / \mathrm{kg}$ body weight, i.v., once a day for 7 days. Within this period, two biofilm control sessions with topical applications of $0.12 \%$ chlorhexidine gluconate were performed. Soft food was given to avoid additional trauma to the surgical sites. Sutures were removed after 7 days under sedation 
with $0.2 \%$ Acepran (Acepromazine, Univer S/A, São Paulo, SP, Brazil).

Sixteen weeks after implant placement, the sites were surgically re-opened for placement of the healing abutments. At the 20th week after implant placement, which is the time necessary for peri-implant mucosa healing, impressions were made with addition-curing silicone (Monopren Transfer, Zhermack) and polysiloxane, condensation-type silicone elastomer (Speedex; Coltène, Altstatten, Switzerland) for fabrication of complete acrylic resin (Cesead 2; Kuraray Co. Ltd., Kurashki, Japan) crowns, which were screwed onto the implants $(n=12)$ with the gingival margins located at the level of the alveolar bone crest (Group I). The mandibular premolars $(n=12)$ adjacent to the implants were prepared to receive complete metal crowns with beveled gingival margins located at the level of the alveolar bone crest. The crowns were made in gold alloy (Goldgato, CNG, Santo Amaro, SP, Brazil) and were cemented to the teeth with zinc phosphate cement (SS White, Rio de Janeiro, RJ, Brazil) (Group II). In both groups, the crowns were placed in infra-occlusion.

\section{In Situ Determination of Alveolar Bone Crest Height}

For in situ assessment of the alveolar bone crest height, the mandibles were dissected, reduced in volume, washed thoroughly in running water, and the gingival tissue was dissected with a scalpel blade. The height of the alveolar bone crest was measured directly on the specimens by the same calibrated examiners using a digital caliper (Mitutoyo Corporation, Tokyo, Japan).

In Group I (implant-supported crowns), this measurement corresponded to the distance between the implant platform and the top of the alveolar bone crest, while in Group II (tooth-supported crowns) this measurement corresponded to the distance between a reference point at the cervical margin of the crown and the top of the alveolar bone crest (Fig. 2). Two sites mesially (mesiobuccal and mesiolingual) and two sites distally (distobuccal and distolingual) to the teeth/ implants were examined. The means of the linear measurements obtained by the 3 examiners in the mesial and distal regions of the teeth/implants were calculated.

\begin{tabular}{|c|c|c|c|c|c|c|}
\hline & 0 & 16 weeks & 20 weeks & 21 weeks & 22 weeks & 38 weeks \\
\hline $\begin{array}{l}\text { (Implant-supported } \\
\text { crowns) }\end{array}$ & $\begin{array}{l}\text { Extraction of } \\
\text { the teeth and } \\
\text { placement of } \\
\text { the implants }\end{array}$ & $\begin{array}{l}\text { Surgical re- } \\
\text { opening of } \\
\text { implants and } \\
\text { placement of } \\
\text { the healing } \\
\text { abutments }\end{array}$ & $\begin{array}{l}\text { Impression for } \\
\text { fabrication of } \\
\text { custom-made } \\
\text { acrylic } \\
\text { impression } \\
\text { trays }\end{array}$ & $\begin{array}{l}\text { Molding of } \\
\text { transference }\end{array}$ & $\begin{array}{l}\text { Installation of } \\
\text { prosthetic } \\
\text { crowns }\end{array}$ & $\begin{array}{l}\text { Sacrifice of } \\
\text { animals - } \\
\text { In situ } \\
\text { assessment of } \\
\text { the alveolar } \\
\text { bone crest } \\
\text { height }\end{array}$ \\
\hline
\end{tabular}

\section{Group II \\ (Tooth-supported crowns)}

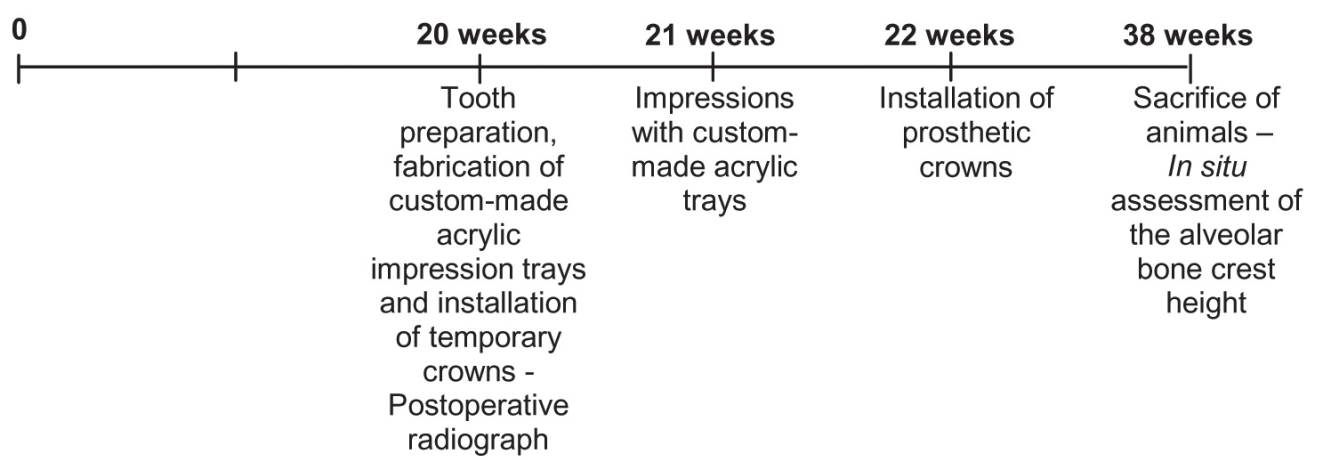

Figure 1. Summary of the clinical procedures and timelines of the study. 

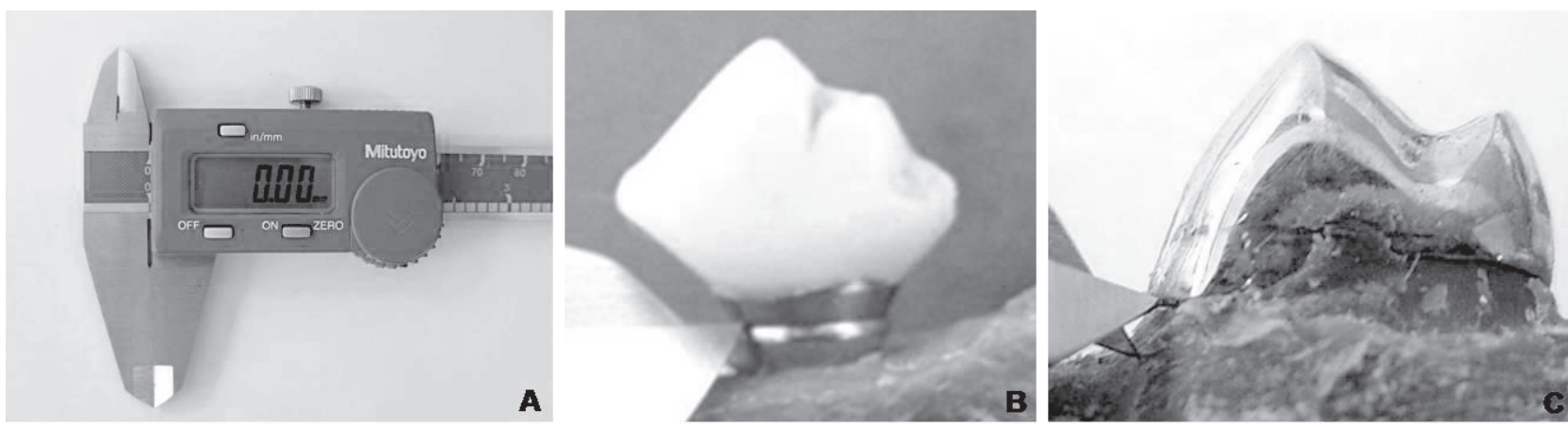

Figure 2. In situ measurements of the alveolar bone crest heights 16 weeks after crown placement (38 weeks after the beginning of the study). A: Digital caliper used in the study. B: In Group I (implant-supported crowns), the measurement corresponded to the distance between the implant platform and the top of the alveolar bone crest; C: In Group II (tooth-supported crowns) the measurement corresponded to the distance between a reference point at the cervical margin of the crown and the top of the alveolar bone crest.

\section{Statistical Analysis}

The in situ data (in $\mathrm{mm}$ ) of the alveolar bone crest height 16 weeks after cementation of the implant-supported and tooth-supported crowns (38 weeks after the beginning of the study) were compared and analyzed statistically by MannWhitney U nonparametric test, for independent samples at 5\% significance level. Data were expressed as mean \pm standard deviation (SD).

\section{RESULTS}

Four specimens were lost during the study: 2 specimens from Group I due to lack of implant osseointegration and 2 specimens from Group II due to crown displacement. The results of the in situ assessment of the change in the alveolar bone crest height in both groups are presented in Table 1. The data correspond to the means of the 3 examiners in both examined regions (mesial and distal). There was no statistically significant difference $(\mathrm{p}=0.880)$ between Group I (1.528 $\pm 0.459 \mathrm{~mm})$ and Group II (1.570 \pm $0.263 \mathrm{~mm})$.

\section{DISCUSSION}

Peri-implant bone loss is an important factor to
Table 1. In situ assessment of the height (in $\mathrm{mm}$ ) of the alveolar bone crest as measured 16 weeks after placement of the crowns ( 38 weeks after the beginning of the study). Data correspond to the means of the 3 examiners in the mesial and distal regions.

\begin{tabular}{lcc}
\hline Specimen & $\begin{array}{c}\text { Group I } \\
\text { (Implant-supported crowns) }\end{array}$ & $\begin{array}{c}\text { Group II } \\
\text { (Tooth-supported crowns) }\end{array}$ \\
\hline 1 & 1.085 & 1.452 \\
2 & 1.040 & 1.645 \\
3 & 1.030 & 1.510 \\
4 & 1.010 & 1.355 \\
5 & 1.605 & 1.500 \\
6 & 1.545 & 1.595 \\
7 & 1.810 & 1.190 \\
8 & 2.135 & 1.480 \\
9 & 1.890 & 2.140 \\
10 & 2.130 & 1.835 \\
Means \pm SD & $1.528 \pm 0.459^{*}$ & $1.570 \pm 0.263 *$ \\
\hline
\end{tabular}

*Mann-Whitney U-test for independent samples $(\alpha=5 \%)$. There was no statistically significant difference $(\mathrm{p}=0.880)$ between the groups.

determine the long-term success of dental implants (7). For this reason, this study investigated whether the placement of crowns retained by either immediate implants or natural teeth with margins located at the bone level and without incidence of occlusal load would induce changes in the alveolar bone crest height. The outcomes showed that the ability of immediate implants to maintain the alveolar bone crest height is similar to that of natural teeth prepared to support crows. 
Alveolar bone crest loss in two-stage implant systems has been attributed to occlusal load, presence of microorganisms and implant microgap location (14). In the present study, the crowns were placed in infraocclusion in order to minimize the influence of occlusal load. In addition, as peri-implant bone loss can often be associated with peri-implantitis (15), chemical control of biofilm after implant placement was carried out with topical applications of $0.12 \%$ chlorhexidine gluconate, which is considered as the gold standard of antimicrobial agents (16). According to Ricci et al. (17), rigorous control of dental biofilm can limit alveolar bone crest resorption in 2-stage implants.

Shibli et al. (18) reported that the presence of a microgap between the implant platform and abutment causes a biological condition in which the peri-implant bone tissue is remodeled as if 'seeking to delimit' a space to accommodate the junctional epithelium and the connective tissue that are responsible for peri-implant marginal homeostasis. This space is similar to that of prosthetically restored natural teeth and is known as biological space. A physiological dimension seems to exist between the bone and the crown-implant interface that is established early and maintained over time (12).

Considering that in the present study alveolar crest bone loss, measured in situ, was very similar between implant-supported and tooth-supported crows, it is possible to suggest that the location of the microgap at the alveolar bone crest level together with the presence of microorganisms caused bone resorption in an attempt to re-establish the biological space. Thus, implant placement had not a negative effect on alveolar bone crest. Similar results have been reported also using mandible dog as experimental model (19).

In contrast with some studies $(4,20)$ that reported that implant placement induces alveolar bone crest loss, the results of the present study suggest that changes in the alveolar bone crest height is not caused by the implant itself, but it is rather induced by the location of the crown cervical margin at the bone crest level. It may be concluded that the peri-implant alveolar bone crest loss is due to need of bone remodeling for establishment of the biological space, similar to which occurs with natural tooth-supported crowns.

\section{RESUMO}

O objetivo do presente estudo foi comparar in situ modificações ocorridas na crista óssea alveolar induzidas por implantes imediatos e às induzidas por dentes naturais, ambos preparados para suportarem dispositivos protéticos situados sobre a margem óssea cervical, sem carga oclusal. No grupo I, após a extração de 12 pré-molares inferiores de 4 cães adultos, foram instalados implantes do Sistema Branemark (MK III TiU RP 4,0 x 11,5 $\mathrm{mm}$ ) e coroas totais acrílicas. No grupo II, os pré-molares, foram submetidos a preparos convencionais, sendo cimentadas coroas totais metálicas. Após 16 semanas da instalação das coroas (38 semanas após a extração), a reabsorção da crista óssea alveolar foi avaliada in situ, por meio da mensuração das peças, com paquímetro digital. Para obtenção das medidas do grupo I, os pontos de referência foram a plataforma de assentamento do implante e a crista óssea alveolar. No grupo II, a posição do limite cervical da prótese e o início da crista óssea. Os valores obtidos foram comparados pelo teste de Mann-Whitmey com nível de significância de 5\%. A média de reabsorção da crista óssea foi de $1,528 \pm 0,459 \mathrm{~mm}$ para o grupo I e de $1,570 \pm 0,263 \mathrm{~mm}$ para o grupo II, não havendo diferença estatisticamente significante $(\mathrm{p}=0,880)$ entre os grupos. Os resultados do presente estudo permitiram concluir que a reabsorção perimplantar inicial que ocorre na crista óssea resulta de um padrão de remodelação necessário para o estabelecimento do espaço biológico na área, assim como ocorre nos dentes naturais preparados para receberem próteses convencionais.

\section{REFERENCES}

1. Novaes-Jr AB, Marcaccini AM, Souza SL, Taba-Jr M, Grisi MF. Immediate placement of implants into periodontally infected sites in dogs: a histomorphometric study of boneimplant contact. Int J Oral Maxillofac Implants 2003;18:391398.

2. Evans CD, Chen ST. Esthetic outcomes of immediate implant placements. Clin Oral Implants Res 2008;19:73-80.

3. Schwartz-Arad D, Chaushu G. The ways and wherefores of immediate placement of implants into fresh extraction sites: a literature review. J Periodontol 1997;68:915-923.

4. Schwartz-Arad D, Yaniv Y, Levin L, Kaffe I. A radiographic evaluation of cervical bone loss associated with immediate and delayed implants placed for fixed restorations in edentulous jaws. J Periodontol 2004;75:652-657.

5. Orenstein IH, Synan WJ, Truhlar RS, Morris HF, Ochi S. Bone quality in patients receiving endosseous implant. DICRG Interim Report No. 1. Dental Implant Clinical Research Group. Implants Dent 1994;3:90-94.

6. Schropp L, Kostopoulos L, Wenzel A. Bone healing following immediate versus delayed placement of titanium implants into extraction sockets: a prospective clinical study. Int $\mathbf{J}$ Oral Maxillofac Implants 2003;18:189-199.

7. Bragger U, Hafeli U, Huber B, Hammerle CH, Lang NP. Evaluation of postsurgical crestal bone levels adjacent to non-submerged dental implants. Clin Oral Implants Res 1998;9:218-224.

8. Mombelli A, Lang NP. Clinical parameters for the evaluation of dental implants. Periodontol 2000 1994;4:81-86.

9. van Steenberghe D, Naert I, Jacobs R, Quirynen M. Influence of inflammatory reactions vs. occlusal loading on peri-implant marginal bone level. Adv Dent Res 1999;13:130-135.

10. Malmqvist JP, Sennerby L. Clinical report on the success of 
47 consecutively placed Core-Vent implants followed from 3 months to 4 years. Int J Oral Maxillofac Implants 1990;5:5360 .

11. Choquet V, Hermans M, Adriaenssens P, Daelemans P, Tarnow DP, Malevez C. Clinical and radiographic evaluation of the papilla level adjacent to single-tooth dental implants. A retrospective study in the maxillary anterior region. J Periodontol 2001;72:1364-1371.

12. Hartman GA, Cochran DL. Initial implant position determines the magnitude of crestal bone remodeling. J Periodontol 2004;75:572-577.

13. International Guiding Principles for Biomedical Research Involving Animals. Geneva, Switzerland: CIOMS (Council for International Organizations of Medical Sciences); (1985). http://www.cioms.ch/frame_1985_texts_of_guidelines.htm. Latest access on March 11, 2008.

14. Avila G, Galindo P, Rios H, Wang HL. Immediate implant loading: current status from available literature. Implant Dent $2007 ; 16: 235-245$.

15. Kozlovsky A, Tal H, Laufer BZ, Leshem R, Rohrer MD, Weinreb M, Artzi Z. Impact of implant overloading on the peri-implant bone in inflamed and non-inflamed peri-implant mucosa. Clin Oral Implants Res 2007;18:601-610.

16. Moshrefi A. Chlorhexidine. J West Society Periodontol 2002;50:5-9.

17. Ricci G, Aimetti M, Stablum W, Guasti A. Crestal bone resorption 5 years after implant loading: clinical and radiologic results with a 2-stage implant system. Int J Oral Maxillofac Implants 2004;19:597-602.

18. Shibli JA, Martins MC, Lotufo RF, Marcantonio-Jr E. Microbiologic and radiographic analysis of ligature-induced periimplantitis with different dental implant surfaces. Int J Oral Maxillofac Implants 2003;18:383-390.

19. Hermann JS, Buser D, Schenk RK, Higginbottom FL, Cochran DL. Biologic width around titanium implants. A physiologically formed and stable dimension over time. Clin Oral Implants Res 2000;11:1-11.

20. Friberg B, Jemt T, Lekholm U. Early failures in 4,641 consecutively placed Branemark dental implants: a study from stage 1 surgery to the connection of completed prostheses. Int J Oral Maxillofac Implants 1991;6:142-146.

Accepted April 17, 2008 